\title{
SEISMIC RESISTANCE OF BRICK MASONRY WALLS
}

\author{
M.J.N. Priestley* and D.O. Bridgeman*"
}

\section{SYNOPSIS}

This paper summarises the results obtained from testing 18 reinforced masonry wall panels under racking load. The programme included tests on both RBM and Hollow Cell types of brick construction under slow cyclic loading. It is shown that satisfactory ductility can be obtained from brick masonry walls if sufficient horizontal steel is provided to carry the full shear load, and if the critical compression zones at the bottom corners of the wall are confined by the use of thin reinforcing plates in the bottom few mortar courses. Without these precautions severe load degradation occurs under successive load reversals.

\section{INTRODUCTION}

Load bearing brick masonry has a poor reputation for seismic resistance. Although this is primarily due to the failure of unreinforced walls and veneers constructed in the 19th Century or the early part of this century, a general lack of confidence in the material by designing engineers is reflected in the strict limitations imposed on both unreinforced and reinforced masonry by the codes of practice of most countries subjected to seismic activity. With the increasing emphasis in reinforced concrete anti-seismic design on the provision of ductile load-limiting response, confidence in brick masonry construction, with its apparent brittleness, has if anything deteriorated further.

Except in very recent years surprisingly little relevant research has been carried out into the seismic resistance of reinforced masonry; whether brick or concrete block. Exceptions to this were the work $9 \frac{f}{3}$, Copverse into some aspects of the flexural and shear strength of both forms of reinforced masonry. However, these early tests were carried out under monotonic loading, or with limited load reversals at loads below ultimate. More recently dynamic tests were carried out by Meli and Esteve (5) in an investigation of the shear strength of mainly concrete block wall panels, and Scrivener and Williams $(6,5)$ investigated ductility capabilities and load degradation of reinforced walls of concrete block and hollow-cell brick forms of construction. However, the brick walls tested in this

* Structural Consultant to N.Z. Pottery and Ceramics Research Association, Head of Structural Laboratory. Ministry of Works and Development Central Laboratories.

** Senior Technical Officer, Masonry Testing Laboratory, N.Z. Pottery and Ceramics Research Association. series were constructed from nominal $108 \mathrm{~mm}$ wide units, which are smaller than the minimum proposed by the draft code on structural masonry $(8)$. No tests were carried out on the larger hollow cell units ( $140 \mathrm{~mm}$ nominal width) or on RBM walls (two skins of solid bricks separated by a reinforced grout gap), which still remain the most common form of structural brick masonry in New Zealand. Results from the tests of Scrivener and Williams were inconclusive, as it appeared that even the most flexural of their walls in some tests displayed severe stiffness ang load degradation. Scrivener concluded $(9)$ "It appears ............ that a sufficiently ductile behaviour cannot be confidently predicted ........... (and masonry) structures must be designed to withstand forces associated with the design earthquake which may be several times the code specified values ............ for ductile framed structures". This was despite the incorporation of non-standard construction details in their walls (reinforcing steel welded to a steel plate forming the wall base; angle shear connectors between steel base and wall) which may have significantly increased the ductility capabilities of their walls.

Mayes et al (10) have recently reported initial results from a continuing series of dynamic, cyclic tests designed to investigate the strength of piers and spandrels in coupled or perforated shear walls. However, this form of construction is not common in New Zealand, where the preference is for providing a series of cantilever walls, linked by comparatively flexible beams, or diaphragm floors.

The tests on brick walls units carried out at the New Zealand Pottery and Ceramics Research Association over the past few years and reported below, represent an attempt to widen the scope of Scrivener and Williams' work into RBM construction and the larger size of hollow brick masonry; to investigate in greater detail the mechanism and control of shear failure in brick, and to develop methods for reducing load degradation.

\section{DESCRIPTION OF WALL PANELS}

The wall panels tested consisted of 14 RBM and 4 hollow cell panels each of unit aspect ratio, and between $1.04 \mathrm{~m}$ and $1.80 \mathrm{~m}$ square. Table 1 summarises wall dimensions, amounts and distribution of deformed reinforcing bars and material properties, for walls F2 to F15 (RBM construction) and $\mathrm{CBU}-1$ to $\mathrm{CBU}-4$ (Hollow Cell construction). All RBM walls were constructed from two skins of nominal $230 \times 75 \times 70 \mathrm{~mm}$ high "Golden Buff" bricks (Amalgamated Brick and Pipe Co. Ltd.), 
separated by a $64 \mathrm{~mm}$ grout gap. The hollow cell walls were constructed from McSkimming Industries 6124 Ceramic Block Units of nominal width $140 \mathrm{~mm}$. All cells were filled.

The main variable in the tests was the amount of reinforcing. Vertical and horizontal reinforcing steel was evenly distributed along the length and height respectively of the walls, except where designated ' $P$ ' in Table 1 , indicating that all vertical steel was concentrated at the ends of the panel. The postscript HY on reinforcing indicates the use of deformed bar of nominal yield strength $=413 \mathrm{MPa}$. In many cases (F7 to F14, CBU-1 to -3) high percentages of vertical steel were included to encourage critical shear conditions to develop.

Except in the case of walls F9 and FlO, all were tested without applied bearing load. This produces conditions where minimum flexural and shear strength result, and represents limiting conditions in linked cantilever wall construction, where low bearing stresses coupled with overturning effects can result in vertical unweighting of individual walls. F13 - F15, CBU-3 and CBU-4 contained mild steel confining plates in the bottom four mortar courses in the vicinity of the wall ends as discussed later.

\section{TESTING}

Each wall was constructed on one of three reusable wall bases. These consisted of two longitudinal reinforced concrete beams separated by a central wedge-shaped gap $90 \mathrm{~mm}$ wide at the base and $50 \mathrm{~mm}$ wide at the top, running the full length of the wall. The two halves were connected by $9-37 \mathrm{~mm}$ diameter horizontal bolts, and were anchored to a strong-floor. Vertical reinforcing for a wall was welded to a steel angle section placed along the bottom of the central gap, which was then filled with concrete. The wall was then constructed on the base in normal fashion. After testing the two halves of the base were separated, the grout gap removed, and the base prepared for the next wall. Normal construction details and tolerances were used wherever applicable.

Racking load was applied to a reinforced bond beam at the top of the wall by an MTS hydraulic actuator of $534 \mathrm{kN}$ static capacity, operating in a closed-loop electro-hydraulic servo system capable of controlling testing on the basis of specified loads or displacements. The double acting actuator was prestressed to the bond beam by 4 high strength bolts passing through the full length of the bond beam and anchored at the far end. reacting against a steel reaction frame, the actuator was able to apply cyclic loading from the one end of the wall. Displacements were measured by strain-gauged deflectometers and dial gauges. Components of the testing system are illustrated in Fig. 1.

Before testing the walls were painted with white undercoat to facilitate crack detection and marking. All panels were tested at comparatively slow rates of loading $(0.1 \mathrm{~Hz}$ or slower) to allow cracks to be located as they formed. Testing at seismic frequencies was not feasible due to limitations in the flow capacity of the hydraulic pump. It is not expected that significant differences of behaviour would have resulted at higher frequencies than used in the test programme.

\section{ULTIMATE FLEXURAL STRENGTH}

Table 2 compares failure loads with the theoretical capacities in flexure and shear of the walls constructed without confining plates in the critical mortar joints. The yield load $\mathrm{P}_{\mathrm{y}}$ is defined as the theoretical load at which the extreme tension bar first attains its yield strain, and the ultimate flexural capacity $P_{U}$ is based on normal reinforced concrete design methods using an assumed brickwork crushing strength of $\mathrm{f}^{\prime} \mathrm{m}=20.7 \mathrm{MPa}, \mathrm{a}$ crushing strain of .003 , and an undercapacity factor of unity. Table 2 also includes the shear capacity of the horizontal reinforcing.

The first five walls listed (F2 - F6) contained only moderate percentages of flexural reinforcing $(\leqslant .25 \%)$ and were expected to exhibit flexural failures. On initial loading these walls sustained loads averaging 148 higher than the theoretical ultimate flexural capacities. This can be explained on the basis of the high steel strains existing at the stage when crushing of the brickwork occurs. As shown in Fig. 2 the low steel percentages typically result in steel strains in the vicinity of $3-5 \%$ in the extreme tensile bar. The end of the yield plateau for N.Z. deformed bars is in the range $1.3 \%$ $2.0 \%$, after which steel stress begins to rise rapidly with increasing strain. At strains of $3-58$. , steel stresses are $10-258$ above yield stress, resulting in the over-strength observed in Walls F2 to F6.

\section{ULTIMATE SHEAR STRENGTH}

Walls F7 to Flo exhibited diagonal shear failures. In the first two, which were tested without bearing load, failure occurred soon after the formation of the diagonal crack, at a rather low average shear stress of $0.71 \mathrm{MPa}$. The failures were sudden, involving large horizontal displacements across the diagonal crack (see Fig. 3) associated with severe load degradation. Walls F9 and Fl0 sustained much higher shear stresses due to the precompression applied by the bearing load.

Examination of Table 2 shows that of walls F7 - Fl0, one wall F8 contained horizontal steel, with a shear capacity roughly half the ultimate flexural capacity, while the others contained no horizontal steel. However, in each wall vertical steel with comparatively low flexural tensions passed through the diagonal crack at $45^{\circ}$, and might thus be supposed to have close to the same shear capacity of an equivalent number of horizontal bars. This is based on a common misconception. Prior to cracking, the principal tensile stresses near the middle of the panel are close to 450 to the vertical resulting in the formation of the diagonal crack. After formation of this crack the situation can 
no longer be represented by stress analyses of an elastic medium. The imposed load is not a true shear loading, and tends to move the top half of the wall horizontally past the bottom, widening the crack horizontally, rather than perpendicular to the crack. As illustrated by Fig. 4 , this results in any properly anchored horizontal steel crossing the crack resisting the shear in direct tension, while vertical steel must carry the load by dowel action.

Thus the shear capacity of $n$ horizontal bars of diameter d crossing the shear crack will be

$$
\mathrm{V}_{\mathrm{H}}=.785 n \mathrm{~d}^{2} \mathrm{fy}
$$

where fy is the yield stress.

The dowel strength of vertical bars crossing the crack can be estimated by assuming a triangular pressure distribution exerted by the bars on the grout, with a maximum value equal to $\mathrm{fg}^{1}$, the crushing strength of the grout, as illustrated by Fig. $5(a)$ and (b). This will result in moments of the form shown in Fig. $5(\mathrm{c})$.

For equilibrium

$$
\begin{aligned}
& V=\frac{f g^{\prime} \cdot d \cdot I}{2} \\
& I=\frac{2 \mathrm{~V}}{f g^{\prime} \cdot d}
\end{aligned}
$$

This will result in a maximum moment in the bar of

$$
\begin{aligned}
M_{\max } & =.064 \mathrm{fg}^{\prime} \cdot d . \mathrm{I}^{2} \\
& =\frac{.256 \mathrm{~V}^{2}}{\mathrm{fg} \cdot \mathrm{d}}
\end{aligned}
$$

Thus, since $M=z$. fy

$$
\begin{aligned}
& \frac{.256 \mathrm{~V}^{2}}{f g^{\top} \cdot d}=\frac{\pi \mathrm{d}^{3}}{32} \cdot f_{Y} \\
& \text { giving } \quad \mathrm{V}=.619 \mathrm{~d}^{2} \sqrt{f_{Y} \cdot f g^{\top}}
\end{aligned}
$$

To compare this with equation (1) it is assumed that

$$
\mathrm{fg}^{\prime}=0.15 \mathrm{fy} \text {. }
$$

This rather high value is adopted to take some account of biaxial stress conditions that may occur in the crushing. Substituting from Equation (3) into Equation (2) gives, for $n$ bars,

$$
\begin{aligned}
& \mathrm{v}_{\mathrm{v}}=.240 \mathrm{nd}^{2} \mathrm{fY}_{\mathrm{Y}} \\
& \text { Thus } \frac{\mathrm{V}_{\mathrm{H}}}{\mathrm{v}_{\mathrm{V}}}=3.27 .
\end{aligned}
$$

indicating that the horizontal steel will be roughly 3 times as efficient as the same amount of vertical steel in carrying the shear load. In fact, this comparison flatters the vertical steel. As the crack opens, the flexural resistance of the steel in dowel action will rapidly reduce, whereas direct tension action of the horizontal bars results in the added protection of strain hardening at large crack widths.

Both Schneider (2) and Scrivener had previously reported that shear reinforcing was effective only up to maximum percentages of $0.2 \%$ and $0.3 \%$ respectively, regardless of the orientation or distribution of the steel. However, examination of their data indicates that in all of these test walls insufficient shear steel was provided to carry the full shear load.

To investigate this further, walls FII and F12 duplicated F7 and F8 except that in both walls sufficient horizontal steel was provided to carry the full shear load associated with a flexural failure, and that in F12, the Grade 40 vertical bars were replaced by HY 60 bars to further increase the flexural failure load, and thus the required shear strength. Both walls sustained loads exceeding their theoretical flexural capacity, and though diagonal shear cracks developed well before the failure load, crack widths were small, and closed up on unloading, indicating the shear steel was remaining elastic. Two further walls, both of hollow cell construction ( $\mathrm{CBU}-1$ and $\mathrm{CBU}-2$ ) with extremely high percentages of both vertical and shear steel (see Table 1) failed in bond along the extreme tension bars. The shear stress at failure, at 1.70 and 1.76 MPa respectively was very high, and again shear cracks were adequately controlled by the horizontal steel.

It is thus apparent, that contrary to the conclusions of earlier researchers, shear steel is effective provided it is designed to carry the fuli shear load, and that very high average shear stresses, based on the gross cross sectional area can be sustained by brick cantilever walls.

\section{LOAD DEGRADATION}

Table 2 lists maximum loads sustained on the first and second load reversals, as well as the initial maxima. As might be expected, walls F7 to Flo, which suffered shear failure, exhibited rapid load degradation on successive reversals of load.

Perhaps less expected was the load degradation displayed by walls with initial flexural failure modes. In all walls this occurred after initial loading to displacement ductilities of the order of 5 .

Fig. 6 shows load deflection curves for typical walls exhibiting flexural failures (F2) and shear failures (F7). The extent of load degradation was such that testing of these early walls was abandoned after two load reversals.

Load degradation was largely the result of instability of the brick work at the toe and heel of the walls, as noted by previous researchers $(7,9)$. On the initial load application, vertical cracks would develop close to the toe in the crushing zone of the wall, and the resulting isolated columns of brickwork were 'blown out' under the combined action of shear and compression. A typical example is shown in Fig.7(a). This resulted in loss of bond for the extreme tension bars on reversal of the load direction, which compounded the effect. Further, after 
initial load reversals, any steel close to such a crushing zone became inadequately supported laterally, and buckled, as shown in Fig.7(b). As this process continued with each load reversal, degradation rapidly increased.

The vertical cracks in the crushing zone are a result of a mis-match of material properties between the weak mortar and the strong bricks, and have been explained by Hilsdorf (1I) as follows: the mortar, with low compression strength crushes first, and in so doing develops a very high poisson's ratio (up to 3.0 or more). This implies large lateral expansions which are resisted by the bricks, which in consequence develop high lateral tensile stresses, and eventually, vertical cracks.

\section{REINFORCING AGAINST LOAD DEGRADATION}

Scrivener (9) recognised the desirability of confining the mortar beds to reduce the lateral expansions of the crushing mortar, but earlier prism tests by Scrivener and Williams (12) using a coarse mesh of small diameter wires embedded in the mortar had proven ineffective. As it was felt that the amount of joint reinforcing used by Scrivener and Williams was insufficient, walls Fl3 to F15, CBU-3 and CBU-4 were constructed with confining plates in the bottom four courses at each end of the wall. The $3 \mathrm{~mm}$ thick $x 400 \mathrm{~mm}$ long stainless steel plates, shown in Figs. 8 and 9 were placed in the mortar courses during normal construction. Width of the plates was such as to give $12 \mathrm{~mm}$ cover to the wall faces and ends, to allow normal pointing of the courses. Holes were precut in the plates to allow reinforcing bars and grout to pass through unimpeded, and to improve bonding with the mortar. As well as restricting lateral expansions of the mortar, and thus eliminating vertical cracking of the bricks, the plates were expected to provide strong support against buckling of compression steel after a previous tensile yield excursion. No particular problems were experienced by the bricklayer in placing the plates during normal bricklaying operations.

The reasoning applied to the provision of mortar bed confining plates, as outlined above, throws some doubts on the applicability of the results of Scrivener and Williams. As their walls were constructed directly onto steel base plates, these could be expected to have provided significant lateral restraint to the critical bottom mortar course. As a result, vertical cracking would have been delayed, preserving structural integrity to higher ductility values. This could explain the greater severity of load degradation of walls tested at PACRA than experienced in the Canterbury University tests.

\section{RESULTS OF WALLS CONTAINING CONFINING PLATES}

Two of the five walls tested with confining plates (FI5 and CBU-4) contained typical percentages of flexural reinforcing, but sufficient shear steel to carry the full flexural failure load. The other three walls contained higher percentages of steel to investigate the capabilities of the confining plates under conditions which could be. considered to be the most severe conceivable in design practice. Of these, two walls Fl3 and Fl4 were virtual duplicates; the sole differences being the provision of HY60, rather than Grade 40 steel as shear reinforcing for Fl4.

All five of the walls displayed greatly improved behaviour in comparison with the earlier walls. Effective confinement of the crushing zones was obtained throughout the cyclic loading sequences for the RBM walls, despite displacement ductility factors (based on the deflection on first attaining yield load) as high as 16 for wall Fl5. The crushing zones of hollow cell walls were also adequately confined for ductility factors up to 5 , but at higher levels, face shells tended to separate from webs under the action of shear, and in some cases, fell from the walls. It appears that bond between the grout and the smooth moulded surface of the ceramic block units was poor. Fig. 10 shows the condition of the confined zones of FI3 and CBU-3 after 3 cycles at $\pm 25 \mathrm{~mm}$ displacement (D.F. $\approx 5$ ). Compare these with Fig. 7. Fig. 11 shows the general condition of walls at this stage of loading.

Load deflection hysteresis loops for F13, F15, CBU-3 and CBU-4 are shown in Figs. 12 to 15 respectively. The behaviour of Fl4 was effectively the same as for Fl3, and is not separately discussed. Testing took the form of a number of cycles at a series of increasing ductility factors. The characteristics of each wall are briefly summarised below.

\section{Walls F13 (and F14)}

After an initial cycle to yield displacement (D.F. = 1) Fl3 was given 3 cycles at each of D.F. $=2.5,4.4$ and 6.3 , as shown in Fig. 12. In each case an initial maximum load about $10 \%$ below the full theoretical ultimate flexural capacity was obtained in each direction. Significant degradation occurred between the first and second cycle at each ductility factor, but subsequent cycles showed little further degradation, with peak loads after three cycles still being in excess of yield load. on increasing the ductility factor after 3 cycles at a specific displacement a new maximum load of the same order as the initial maximum was attained, and thus stiffness degradation, but no load degradation was occurring. The maximum load of $440 \mathrm{kN}$ was $0.93 \mathrm{Pu}$, and it is felt that under monotonic loading, the full capacity would have been achieved. Average shear stress at maximum load was $1.25 \mathrm{MPa}$.

\section{Wall F15}

Load deflection behaviour, shown in Fig. 13 for D.F. = 1 to D.F. = 10, was similar to that for Fl3 and Fl4, with initial load degradation to a value close to the yield load, but with restoration of the load capacity by increasing the ductility factor, again indicating stiffness, rather than load degradation. After cycling at D.F. = 10, the displacements were increased to D.F. $=16$, where an initial maximum load of $0.97 \mathrm{Pu}$ was attained. A fatigue fracture 
of two reinforcing bars occurred after 7 cycles at D.F. = 16. The maximum load attained was $0.99 \mathrm{Pu}$.

Wa11 $\mathrm{CBU}-3$

This wall contained $1.07 \%$ of vertical (flexural) reinforcing, and successfully withstood shear stresses as high as 1.63 MPa without signs of distress. Behaviour as shown by Fig. 14 followed the same lines as the previous two walls. The maximum load of $348 \mathrm{kN}$ was $0.90 \mathrm{Pu}$. It is felt that the full flexural capacity would have been exceeded under monotonic loading.

\section{WaI1 $\mathrm{CBU}-4$}

Behaviour is shown in Fig. 15. A maximum load of $147 \mathrm{kN}(0.98 \mathrm{Pu})$ was achieved. Stiffness degradation was similar to the previous walls, though stable hysteresis loops formed at about $0.8 \mathrm{P}_{y^{\prime}}$ somewhat lower than the other walls.

In all of these walls, stiffness degradation was the result of sliding of the wall along the base, and to a lesser extent along the 2nd and 3rd mortar courses. As indicated in Fig. 12 the extent of base sliding was as high as 60 of of the total displacement. It is apparent that this resulted from successive yielding of the bars at each end of the wall, creating a continuous open crack of several millimetres width from end to end of the wall at low applied load. As the load was increased during cycling, the base and wall at the compression end of the crack were gradually forced into contact, and sliding ceased. This behaviour is a function of the smooth interface between the wall and the base, and could perhaps be improved by extensive roughening of the base. In scrivener and williams tests $(6,7)$ this form of degradation would have been substantially reduced by the angle shear connectors which were welded to the steel base plate.

Nevertheless all walls, and in particular the RBM walls, showed an ability to sustain several cycles of loading at ductility factors of 4 or more, with the peak loads remaining above, or close to the yield load. It is felt that a conservative design approach would base ultimate behaviour on the yield capacity, rather than the full ultimate capacity, and design for ductility factors of 4 .

\section{CONCLUSIONS}

1. Under monotonic loading, the strength of walls failing in flexure exceeded the theoretical ultimate flexural capacity by an average of $14 \%$ due to the effect of strainhardening the tension steel.

2. Contrary to the conclusion of earlier researchers, shear steel is effective in improving the ultimate shear capacity of masonry, provided sufficient shear steel is provided to carry the full ultimate flexural load. It is felt that the normal undercapacity factor for shear is low enough to ensure adequate shear strength despite possible flexural overstrength resulting from strain-hardening. This is confirmed by one wall, FI3, which contained marginally less horizontal steel than theoretically required to carry the full shear force, but still gave satisfactory behaviour. 3. Horizontal steel is approximately three times as efficient as vertical steel in carrying the shear force across a diagonal crack.

4. Results of dynamic tests by earlier researchers may have been non-conservative due to non-standard conditions at the base of the walls.

5. Load degradation was effectively eliminated at ductility factors up to 5 by the inclusion of stainless steel confining plates in the bottom few mortar courses at each end of the wall. These confined the crushing zone, thus eliminating vertical tension cracks in the bricks, and provided restraint against buckling of the compression steel. The cost of these plates is small in comparison with the benefits that accrue from their use. Further research is needed into the optimum design of confining steel.

It should be emphasised that confining plates are only required in regions where crushing is expected. In general. protection for the bottom 400 to $500 \mathrm{~mm}$ should be adequate for practical cantilever wall design. The length of the plate should adequately protect the full length of the compression block, and the authors favour a detail that extends just past the second vertical bar from the wall end, to provide additional support against compression buckling of the extreme bar. It is expected that mass production techniques would result in a unit price of $\$ 3-\$ 4$ for the confining plates.

6. For walls with adequately confined crushing zones, it is suggested that a conservative seismic design approach would involve use of the first-yield load rather than the ultimate flexural capacity, associated with a ductility factor of 4. However, it should be pointed out that satisfactory behaviour would result from use of the full flexural capacity in design, if standarg material and undercapacity factors (13) are used.

7. RBM walls appeared to give slightly better behaviour than the hollow cell units, possibly due to poor adhesion between the face shells and grout in the latter case, and a greater area of confinement in the former.

8. Although the results presented above refer to tests on brick panels, the conclusions should be applicable to all forms of masonry construction.

\section{ACKNOWLEDGEMENTS}

The encouragement of past and present directors of the New Zealand Pottery and Ceramics Research Association, Drs. P. K. Foster and H. J. Percival, is gratefully acknowledged as is the financial assistance of the Golden Kiwi Lottery Distribution Committee. Permission of the Council of the New Zealand Pottery and Ceramics Research Association to publish this work is also acknowledged.

\section{REFERENCES}

1. Converse, F. J., "Tests on Reinforced Concrete Masonry", Building Standard Monthly, Feb. 1946.

2. Schneider, R. R.." "Lateral Load Tests on Reinforced Grouted Masonry Shear Walls", Uni. of Sthn. Calif. Eng. 
Centre Rept. 70-101, Sept. 1959.

3. Scrivener, J. C., "Concrete Masonry Wall Panel Tests", N.Z. Conc. Const. Vol.10, No:7, July 1966 ppl19-125.

4. Scrivener, J. C., "Static Racking Tests on Concrete Masonry Walls", Proc. Int. Conf. on Masonry structural Systems, Texas. Nov. 1967.

5. Meli, R., Esteve, I., "Behaviour of Hollow Masonry Walls Subjected to Alternating Lateral Load". 2nd National Congress on Seismic Engineering. Veracruz, May 1968.

6. Scrivener, J. C., Williams, D. "Behaviour of Reinforced Masonry Shear Walls Under Cyclic Loading", Bull. of N.Z. Soc. for Earthquake Eng., Vol. 4, No. 2 April, 1971.

7. Williams, D., Scrivener, J. C. "Response of Reinforced Masonry shear Walls to Static and Dynamic Cyclic Loading." Proc. 5th World Conf. on Earthquake Eng. Rome, June 1973.

8. Standards Association of N.Z. DZ4210 Code of Practice for Masonry Buildings. Pt. B.

9. Scrivener, J. C., "Reinforced Masonry - Seismic Behaviour and Design", Bull. of N.Z. Soc. for Earthquake Eng. Vol. 5, No. 4, Dec. 1972, pp 143-155.

10. Mayes, R. L., Mostaghel, N. M., Clough, R. W., Dickey, W. L., "Cyclic Tests on Masonry Piers". Bull. of N.Z. Soc. for Earthquake Eng., Vol. 7 No. 3, Sept. 1974.

11. Hilsdorf, H. K., "Investigation into the Failure Mechanism of Brick Masonry Loaded in Axial Compression", Proc. Int. Conf. on Masonry Structural Systems, Texas, Nov. 1967.

12. Scrivener, J. C., Williams, D., "Compressive Behaviour of Masonry Prisms". Proc. 3rd Australian Conf. on the Mechanics of Structures and Materials, Auckland, Aug. 1971.

13. Standards Association of N.Z. , "Draft N.z. Code of Practice for General Structural Design and Design Loadings D2 $4203 / 301$ to 304 . 
TABLE 1.

WALL PANEL DIMENSIONS AND PROPERTIES

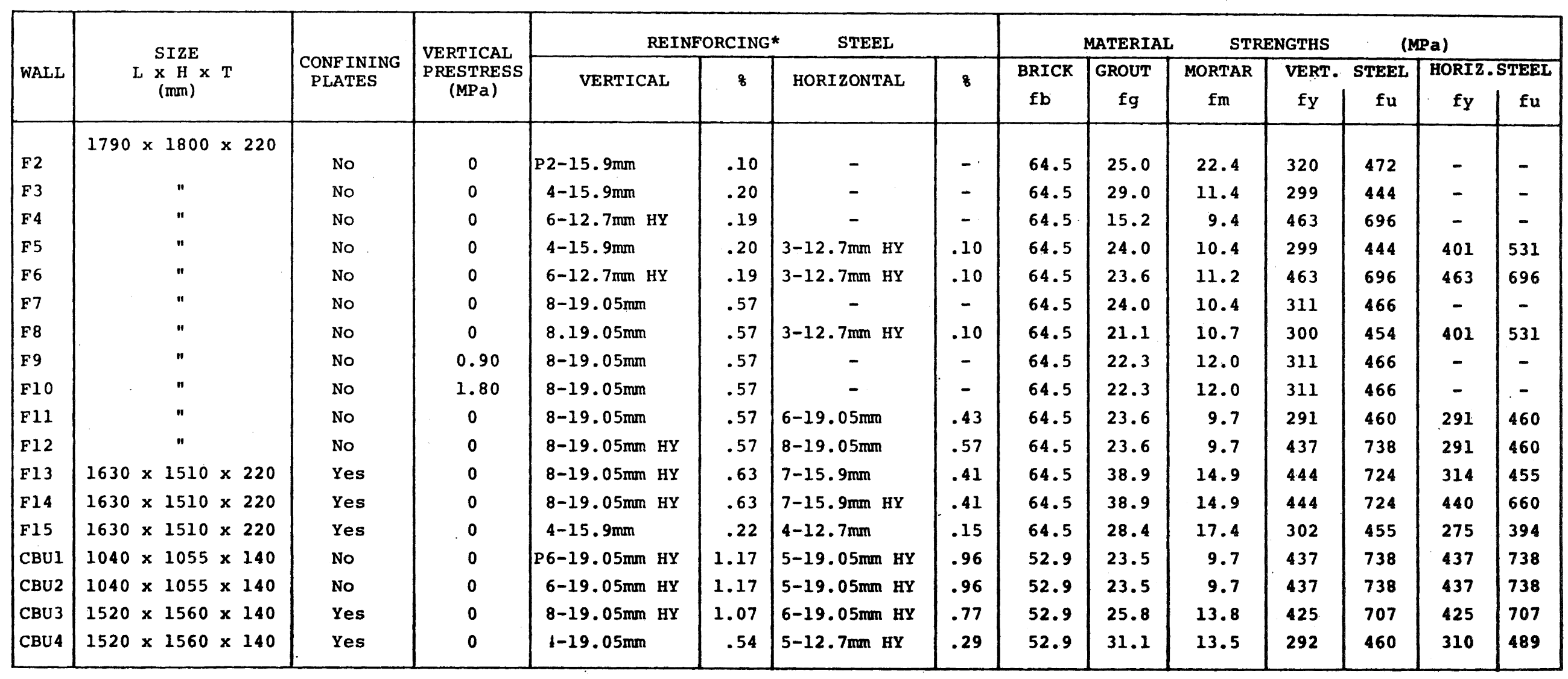

* Deformed Bar Throughout 
TABLE 2.

FAILURE LOADS FOR WALLS WITHOUT CONFINING PLATES

\begin{tabular}{|c|c|c|c|c|c|c|c|c|c|c|c|}
\hline \multirow[b]{2}{*}{ WALL } & \multicolumn{3}{|c|}{ THEORETICAL LOADS $(\mathrm{kN})$} & \multirow{2}{*}{$\begin{array}{l}\text { FAILURE } \\
\text { MODE }\end{array}$} & \multicolumn{3}{|c|}{ EXPERIMENTAL LOADS (kN) } & \multirow{2}{*}{${ }^{\mathrm{Pl}} / \mathrm{Pu}$} & \multirow{2}{*}{$\mathrm{P} 2 / \mathrm{Pu}$} & \multirow{2}{*}{${ }^{\mathrm{P} 3} / \mathrm{Pu}$} & \multirow{2}{*}{$\begin{array}{l}\text { SHEAR STRESS } \\
\text { AT MAX. LOAD } \\
\text { (MPa) }\end{array}$} \\
\hline & $\begin{array}{l}\text { YIELD } \\
\text { PY }\end{array}$ & $\begin{array}{c}\text { ULT. FLEXURAL } \\
\mathrm{Pu}\end{array}$ & $\begin{array}{c}\text { SHEAR } \\
\text { CAPACITY } \\
\text { PV * }\end{array}$ & & $\begin{array}{c}\text { FIRST } \\
\text { LOADING } \\
\text { pl }\end{array}$ & $\begin{array}{c}\text { FIRST LOAD } \\
\text { REVERSAL } \\
\text { p2 }\end{array}$ & $\begin{array}{l}\text { SECOND LOAD } \\
\text { REVERSAL } \\
\text { p3 }\end{array}$ & & & & \\
\hline F2 & 129 & 129 & - & Flexure & 136 & 125 & 85 & 1.05 & .97 & .66 & .34 \\
\hline F3 & 92 & 121 & - & Flexure & 143 & 70 & 98 & 1.18 & .58 & .81 & .36 \\
\hline F4 & 138 & 178 & - & Flexure & 210 & - & - & 1.18 & - & - & .53 \\
\hline F5 & 92 & 121 & 152 & Flexure & 142 & 67 & 35 & 1.17 & .55 & .29 & .36 \\
\hline F6 & 138 & 178 & 176 & Flexure & 197 & - & - & 1.11 & - & - & .50 \\
\hline F7 & 218 & 330 & - & Shear & 276 & 178 & 44 & 0.84 & .54 & .13 & .69 \\
\hline F8 & 212 & 319 & 152 & Shear & 289 & 98 & 52 & .91 & .31 & .16 & .73 \\
\hline F9 & 307 & 462 & - & Shear & 445 & 445 & 125 & .96 & .96 & .27 & 1.12 \\
\hline F10 & 413 & 587 & - & Shear & $533 *$ * & $533 * *$ & 445 & .91 & .91 & .76 & 1.35 \\
\hline FII & 182 & 290 & 497 & Flexure & 300 & 207 & - & 1.03 & .71 & - & 0.79 \\
\hline F12 & 270 & 421 & 662 & Flexure & 427 & 351 & - & 1.01 & .83 & - & 1.12 \\
\hline CBU -1 & 228 & 292 & 620 & Bond & 246 & 175 & - & .84 & .60 & - & 1.70 \\
\hline $\mathrm{CBU}-2$ & 171 & 292 & 620 & Bond & 250 & - & - & .86 & - & - & 1.76 \\
\hline
\end{tabular}

* Based on horizontal steel only.
** Max. capacity of load system. 


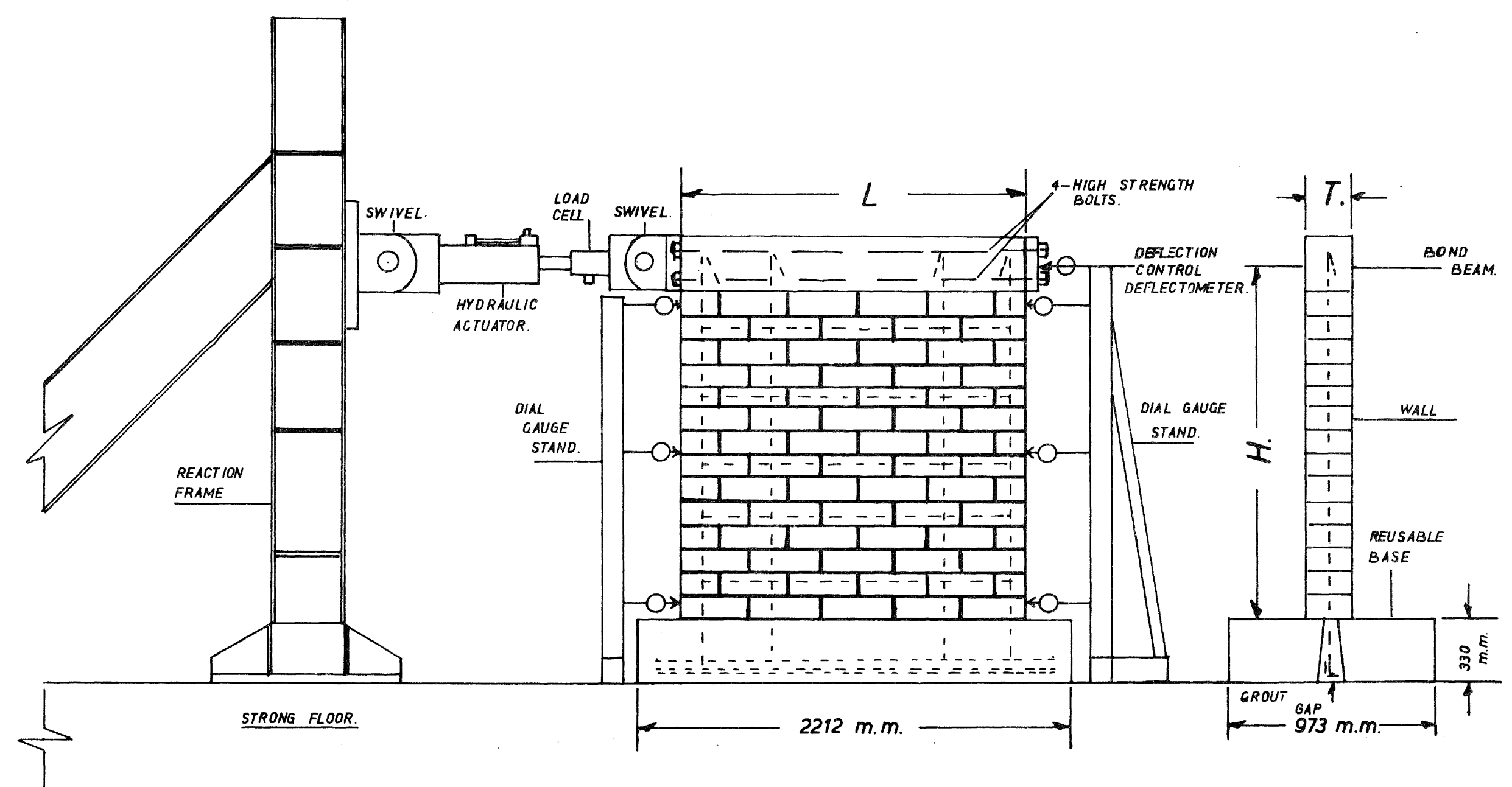

FIGURE 1: MASONRY WALL TEST SET-UP 

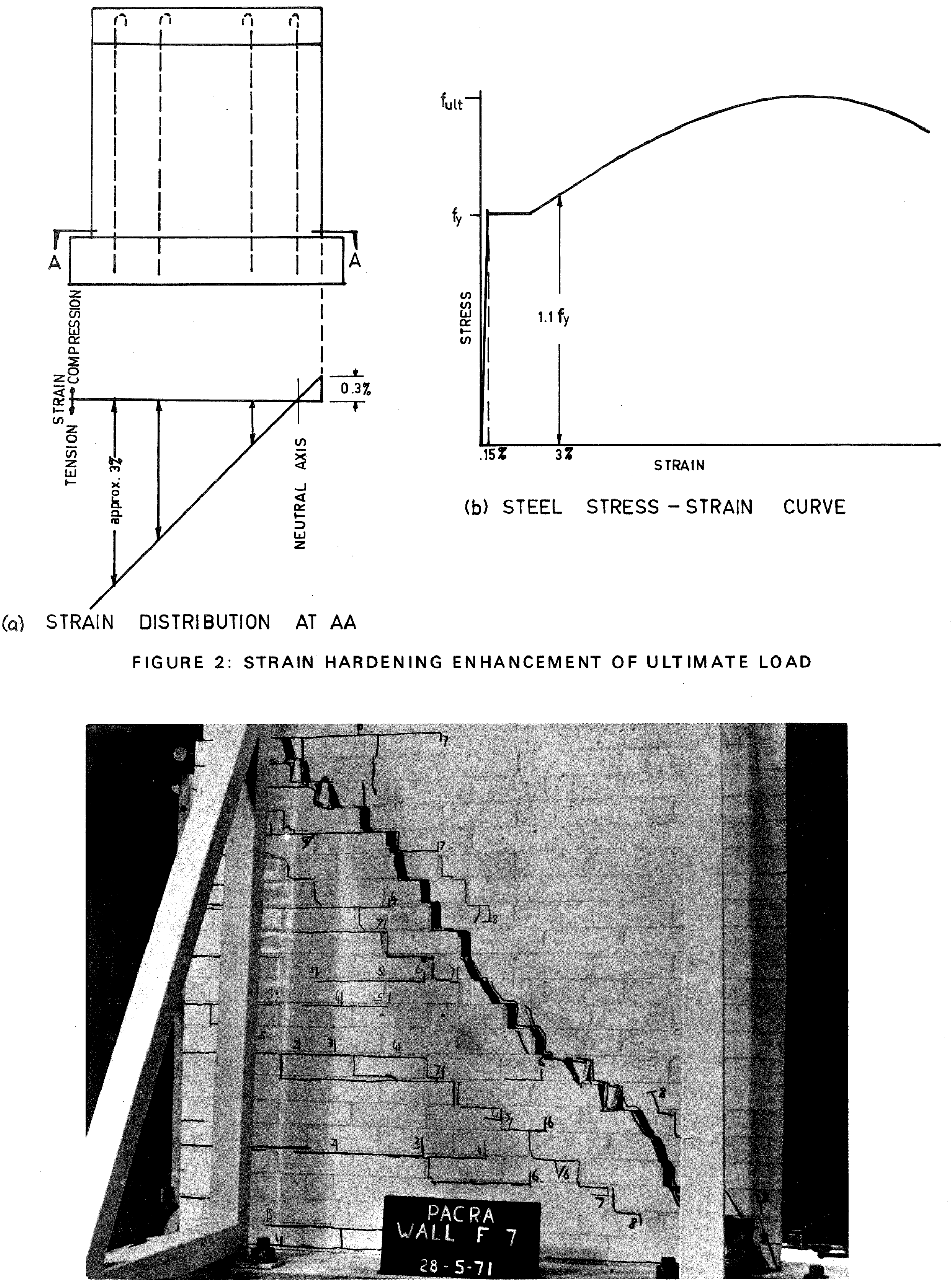

FIGURE 3: TYPICAL SHEAR FAILURE UNDER MONOTONIC LOADING 


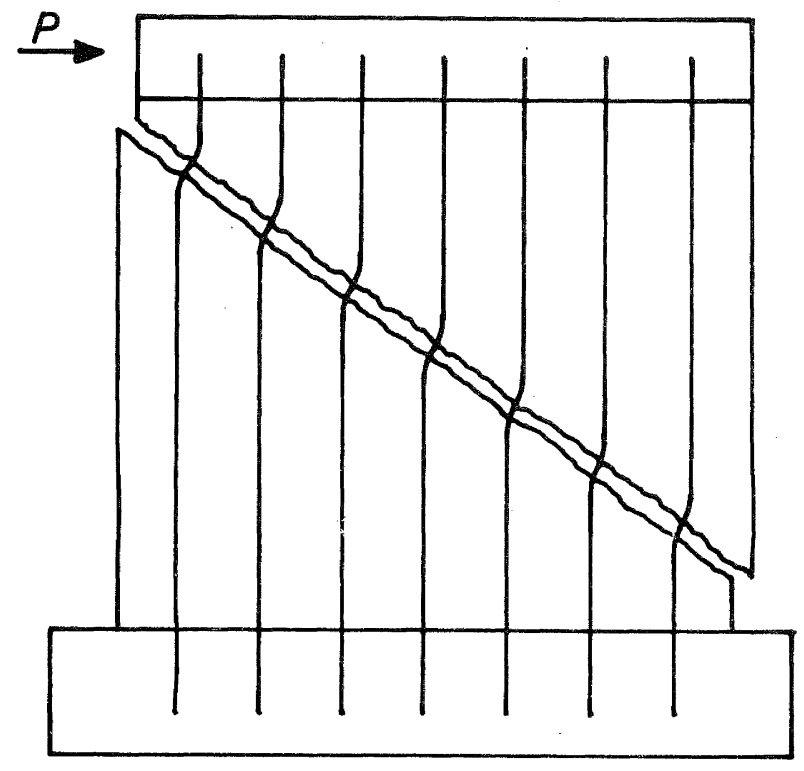

(a) STEEL CARRIES SHEAR BY DOWEL ACTION P.max. $=24 n d^{2}$

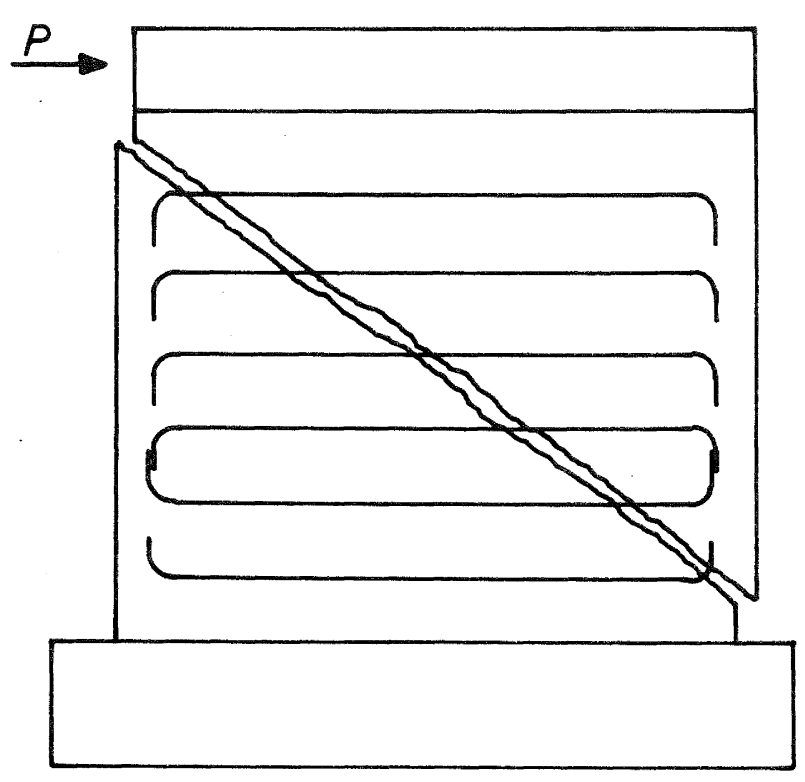

(b) STEEL CARRIES LOAD BY TENSION P.max. $=\cdot 785 n d^{2}$

FIGURE 4: RELATIVE EFFECTIVENESS OF VERTICAL AND HORIZONTAL SHEAR STEEL

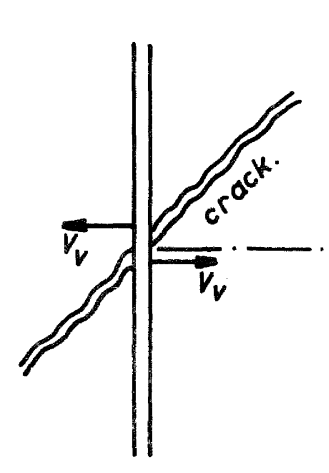

(a) Forees

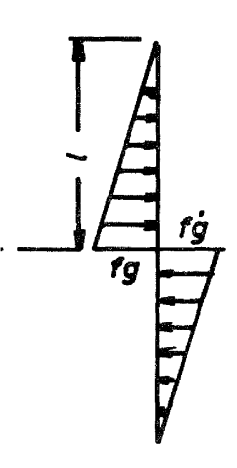

(b)
Grout Pressure on bar.

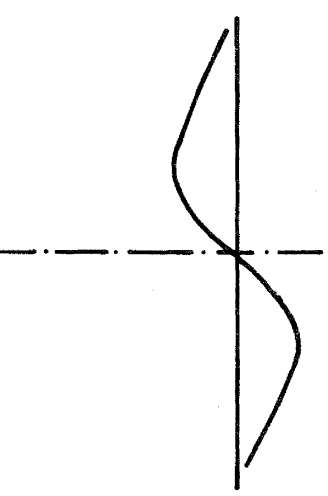

(c) Moments.

FIGURE 5: SHEAR TRANSFER BY DOWEL ACTION 


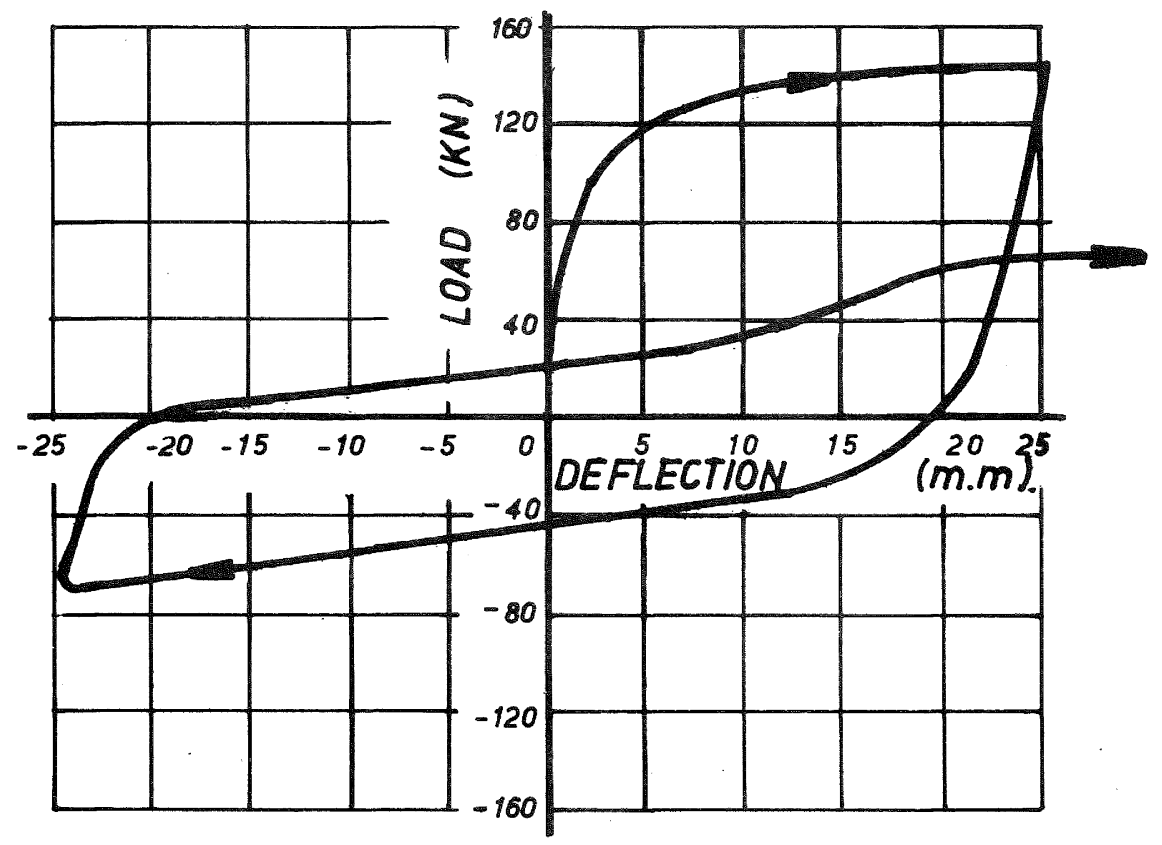

(a) FLEXURAL FAILURE. WALL F2.

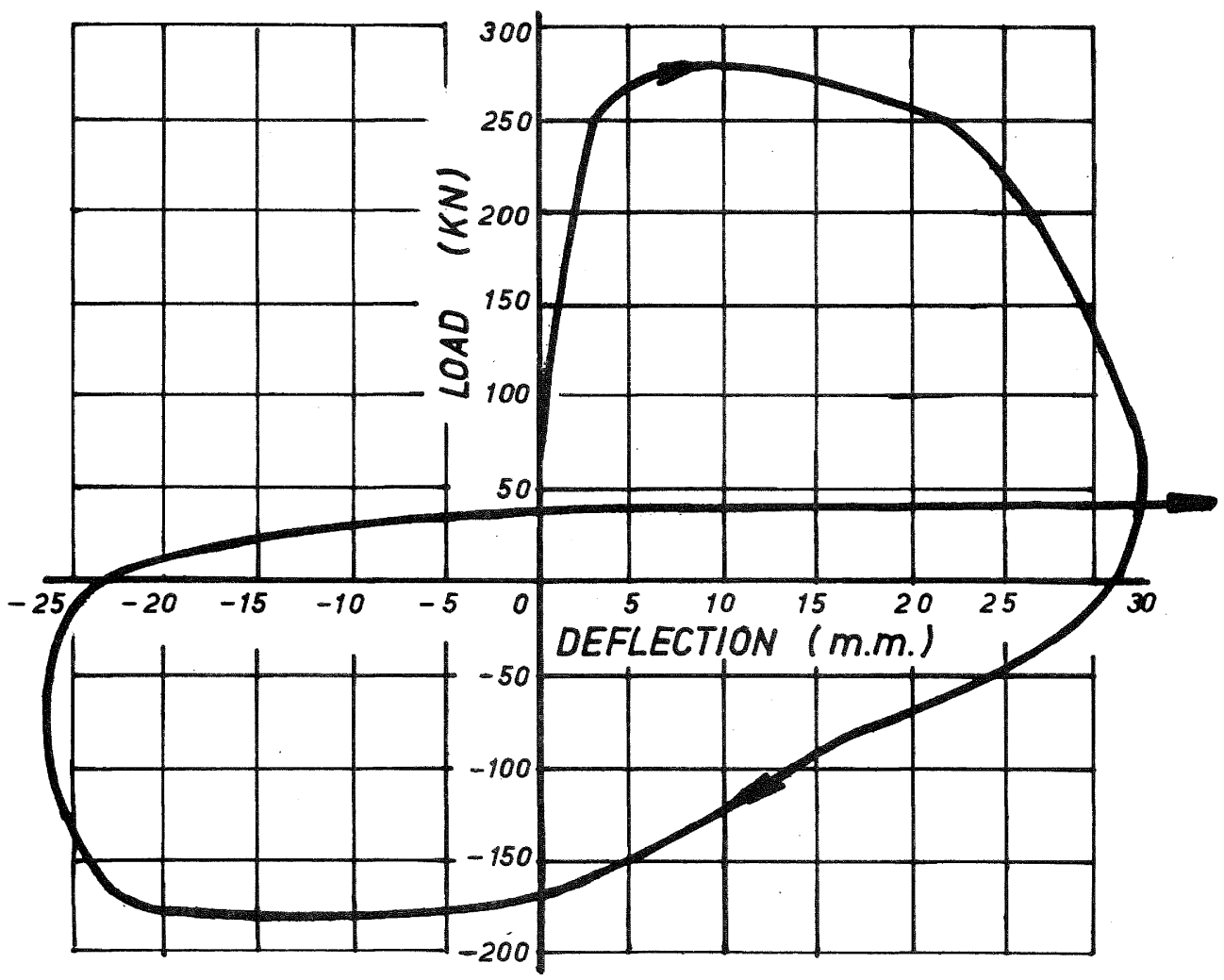

(b). SHEAR FAILURE WALL F 7.

FIGURE 6: WALLS WITHOUT CONFINING PLATES. CYCLIC LOAD DEGRADATION 


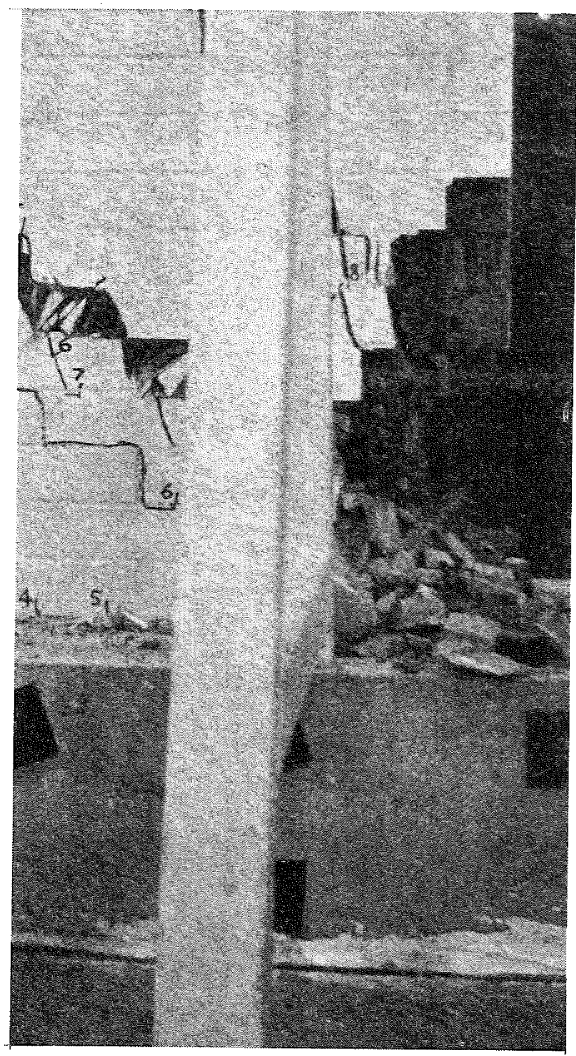

FIGURE 7:

(a) UNCONFINED COMPRESSION ZONE FAILURE
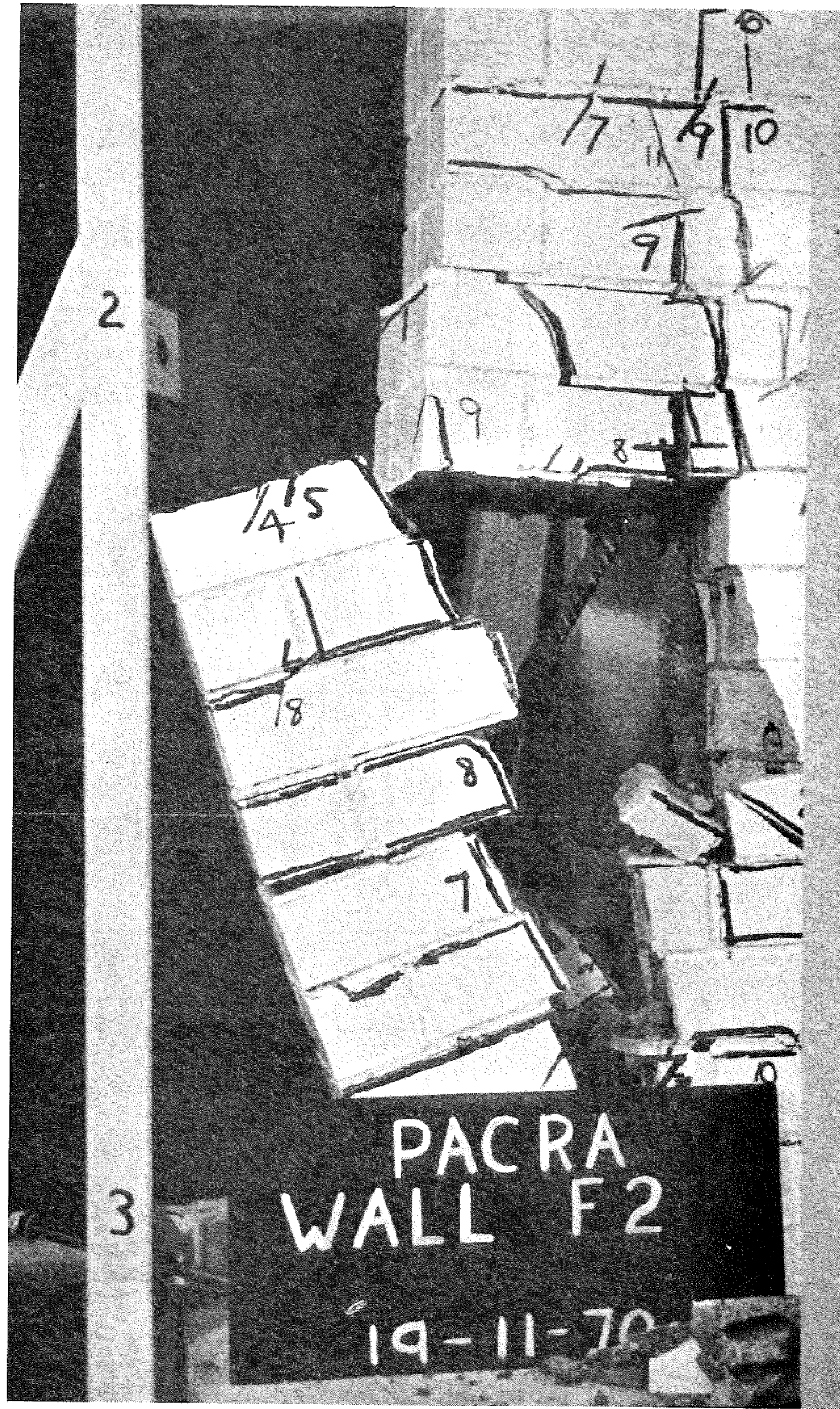

(b) BUCKLING OF PREVIOUSLY YIELDED REINFORCING 
180

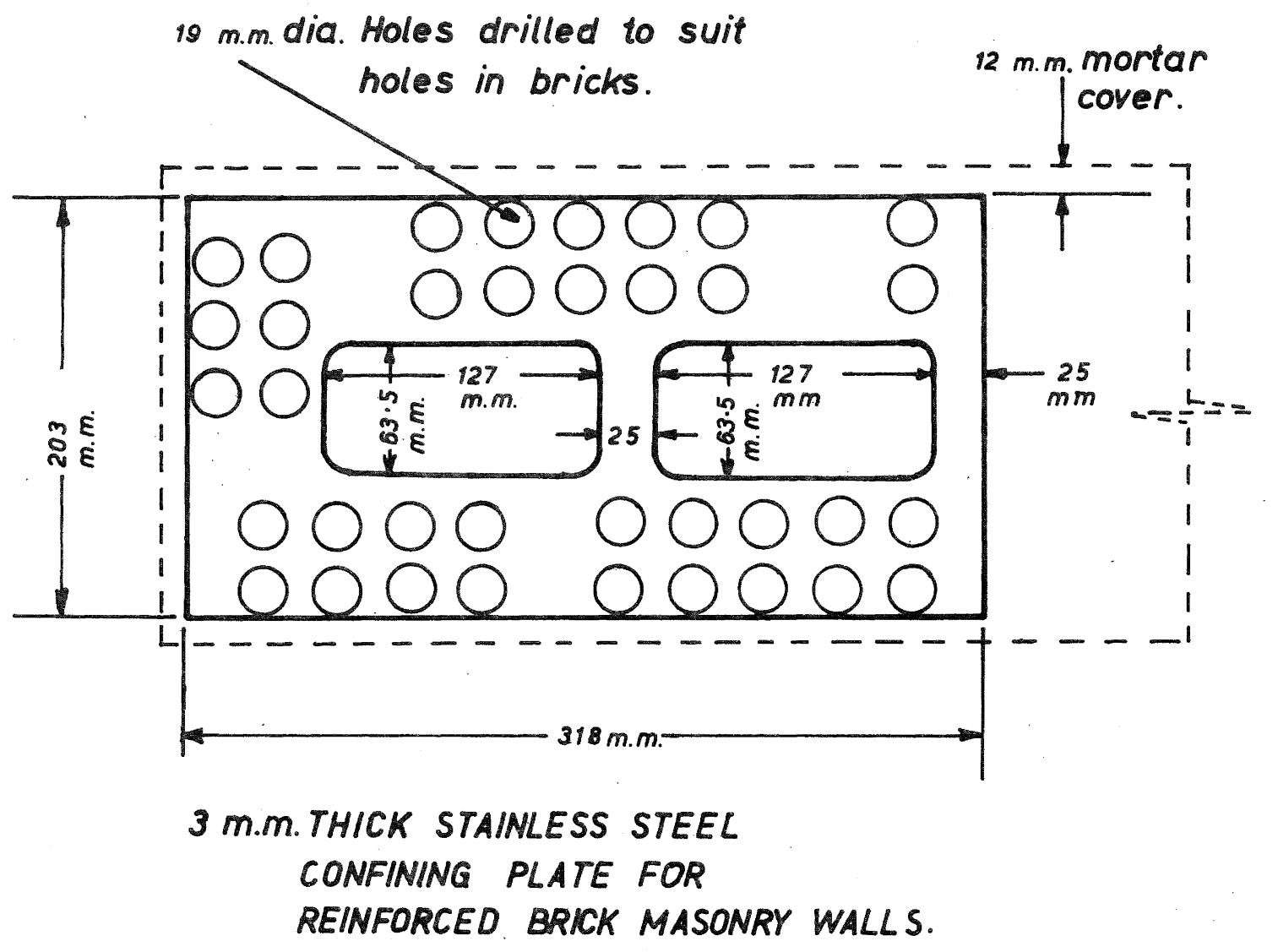

Holes cut out to suit C.-B-U. cells.

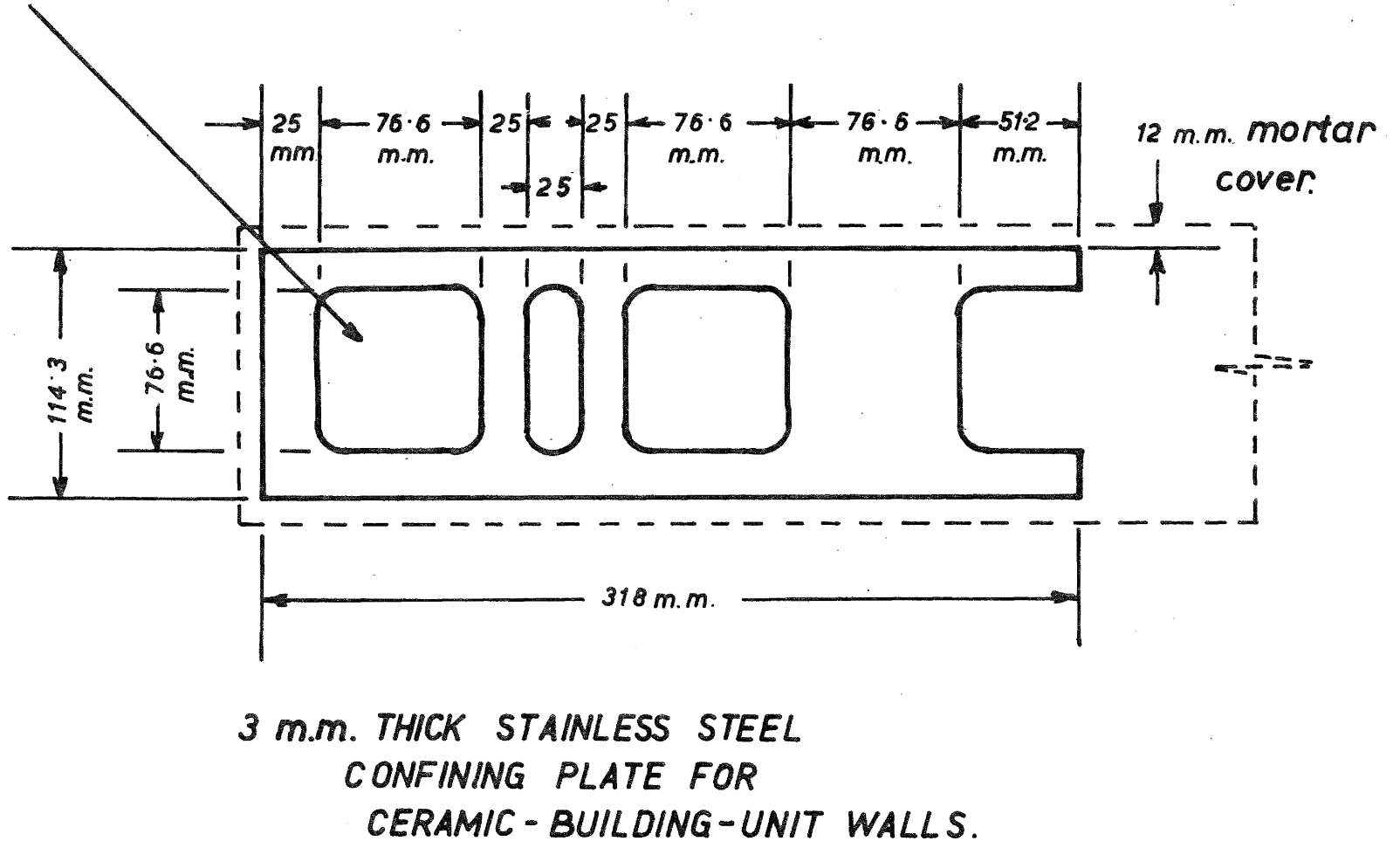




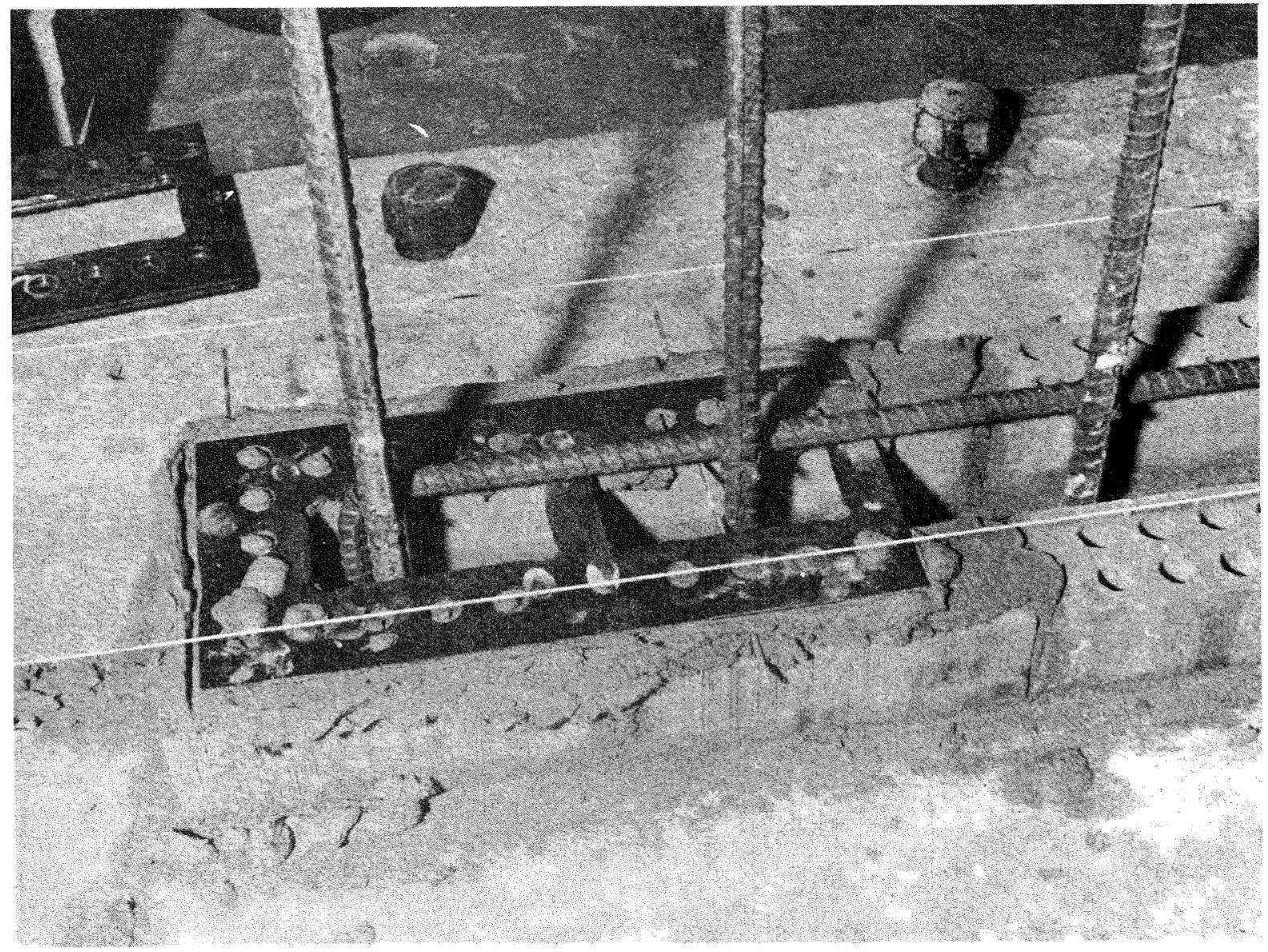

FIGURE 9: (a) CONFINING PLATE IN RBM CONSTRUCTION

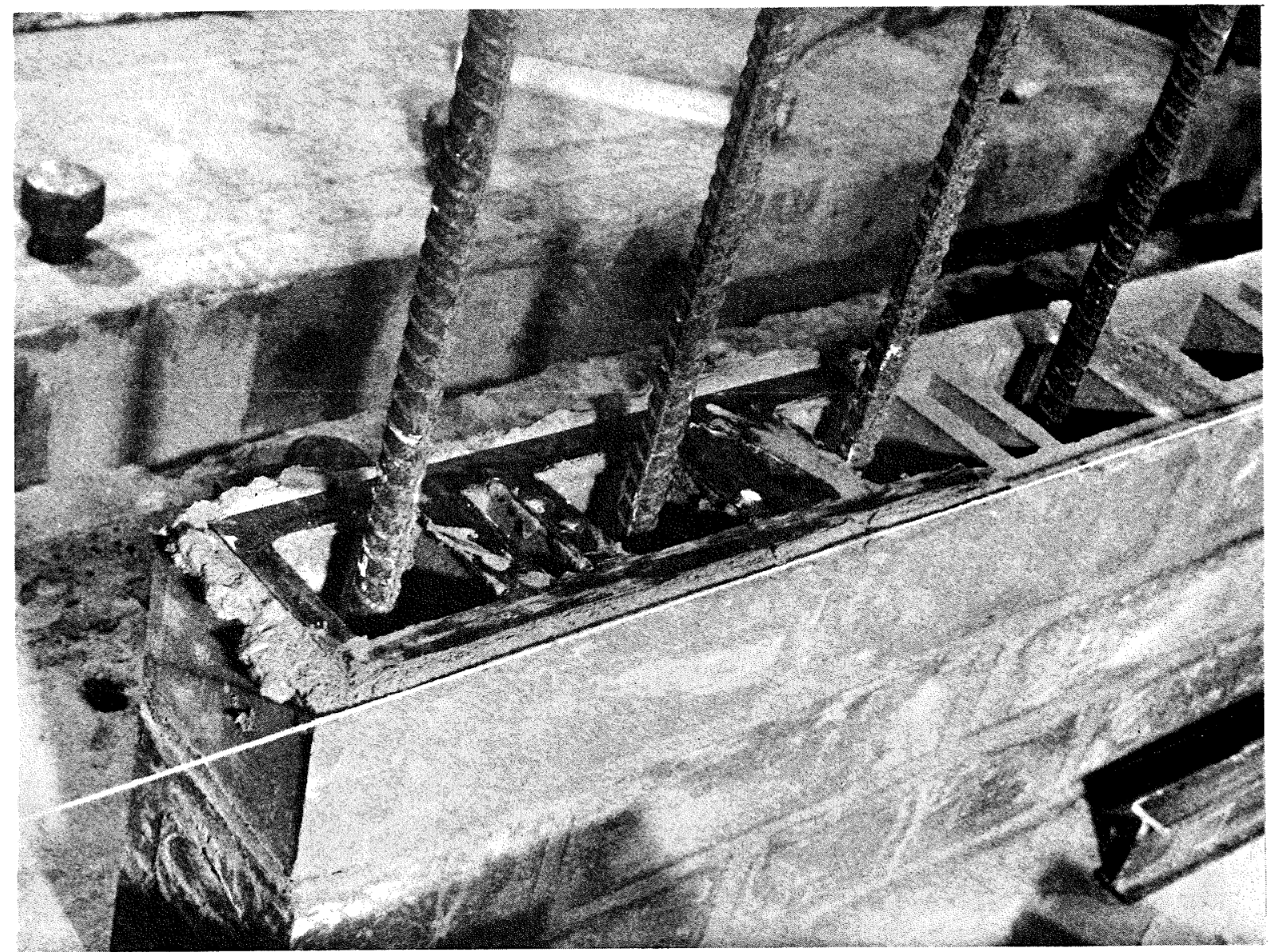

(b) CONFINING PLATE IN HOLLOW CELL CONSTRUCTION 


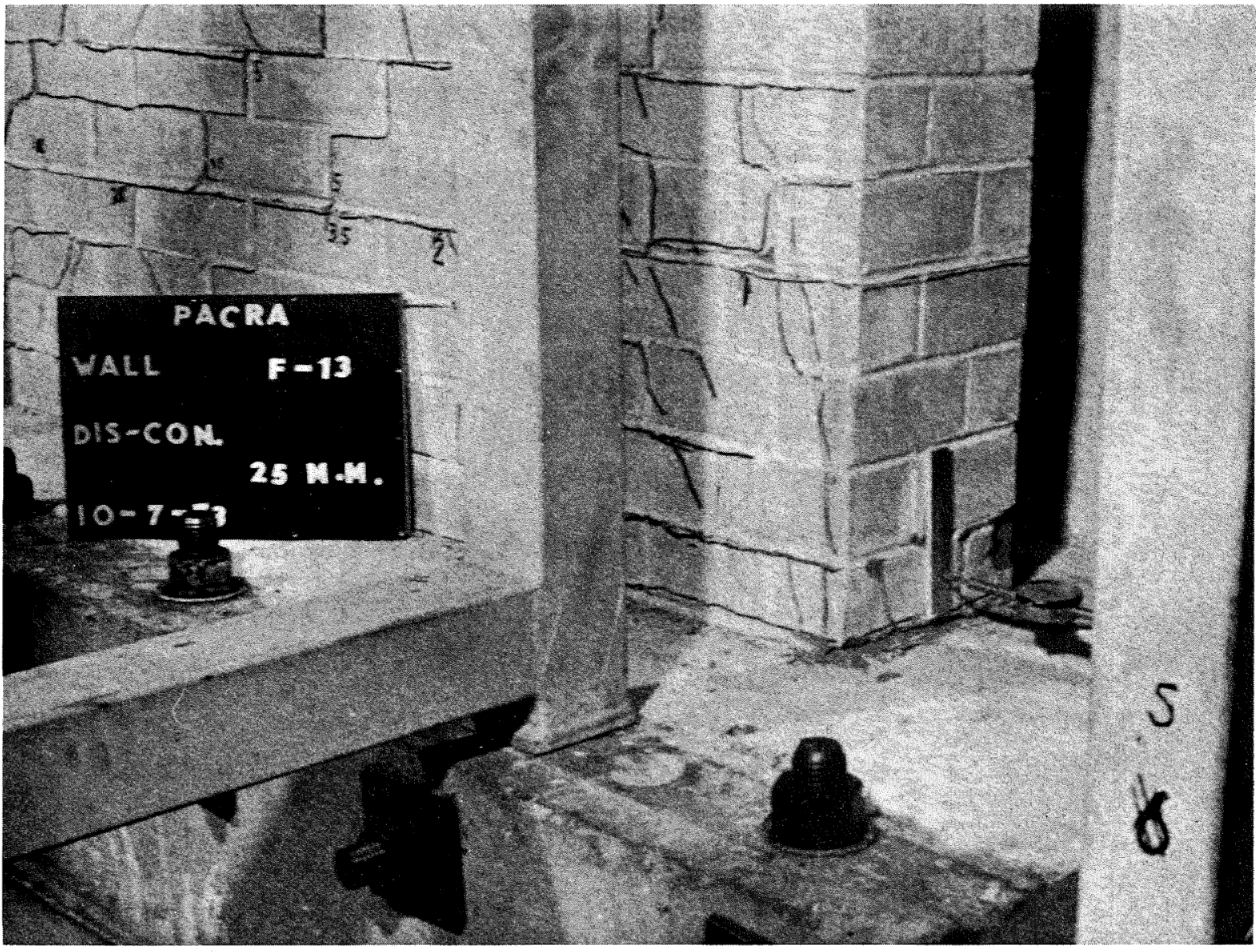

FIGURE 10:

(a) F13 - CONFINED CRUSHING ZONE AFTER CYCLING AT $\pm 25 \mathrm{~mm}$ (D.F. $=6.3$ )

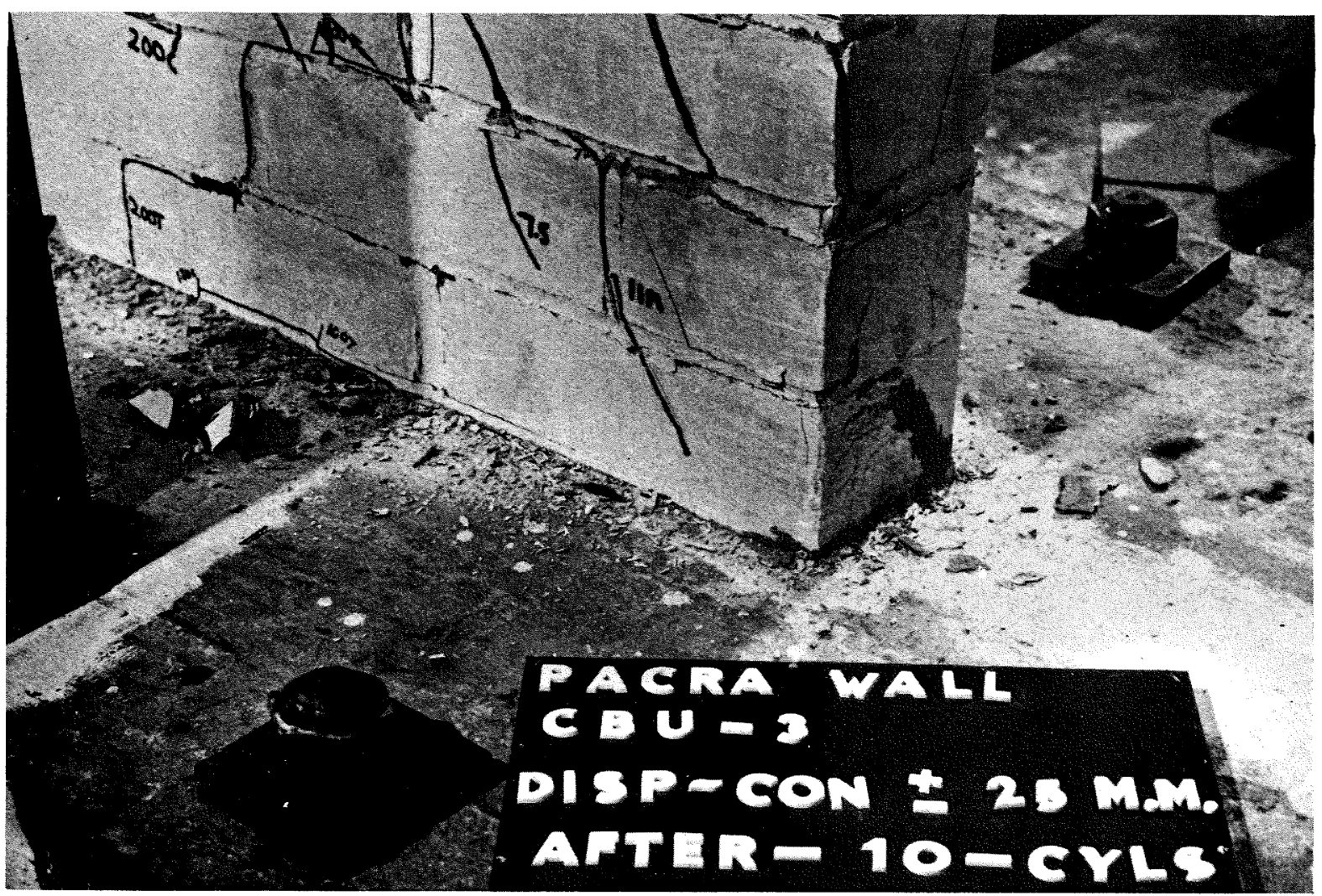

(b) CBU-3 CONFINED CRUSHING ZONE AFTER CYCLING AT $\pm 25 \mathrm{~mm}$ (D.F. $=5.0$ ) 


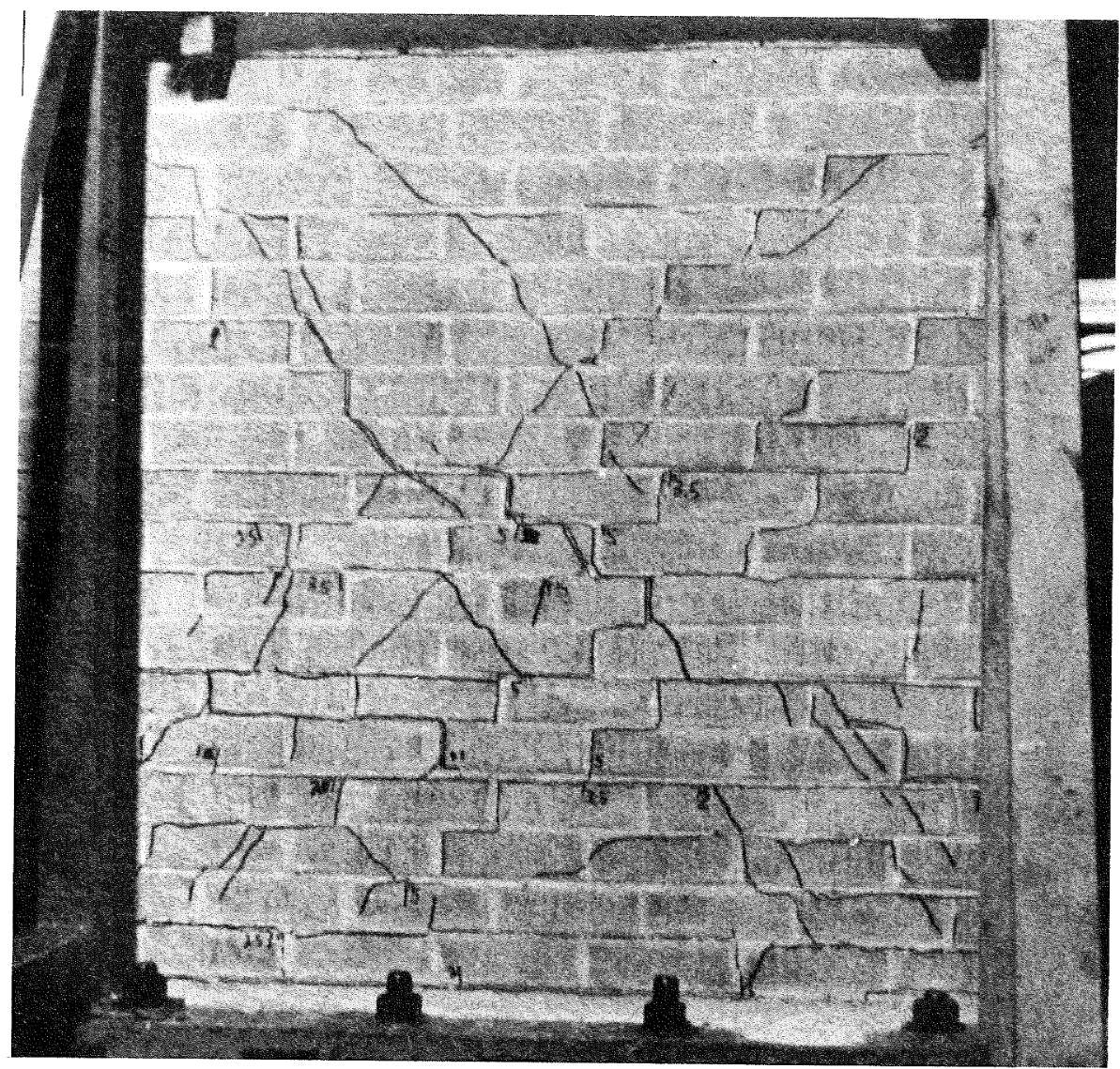

FIGURE 11: (a) F13 AFTER CYCLING AT $\pm 25 \mathrm{~mm}$

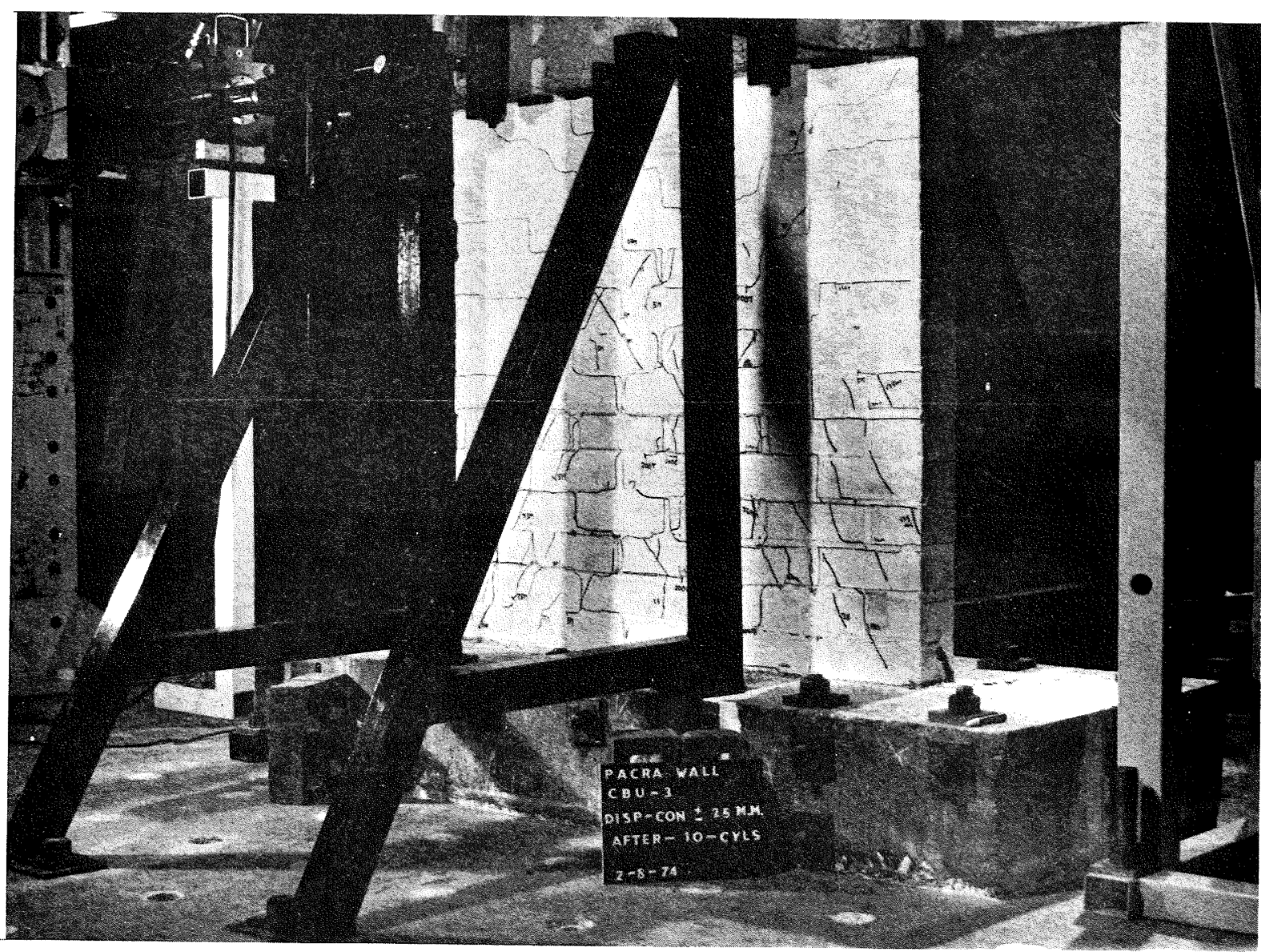

(b) CBU-3 AFTER CYCLING AT $\pm 25 \mathrm{~mm}$ 


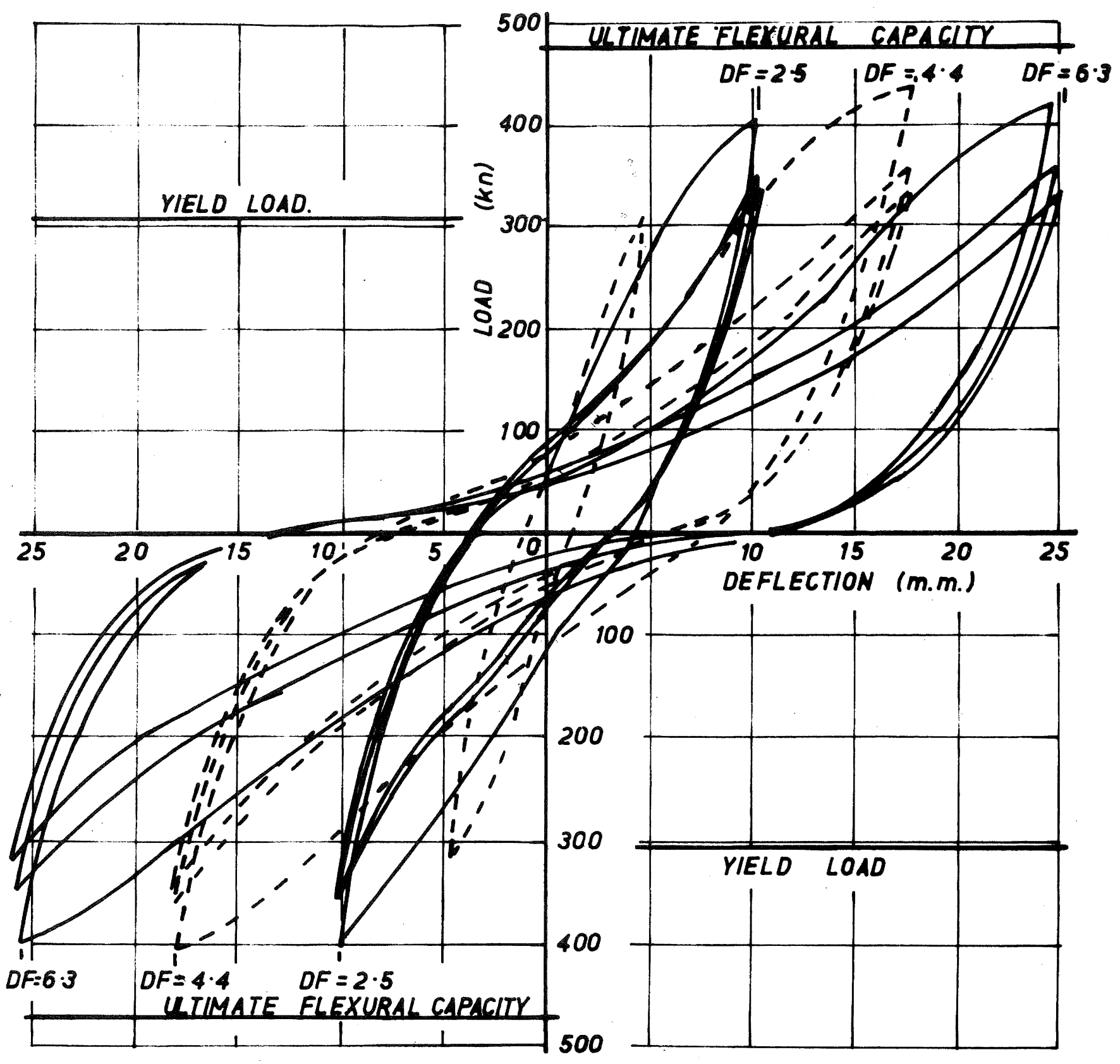

FIGURE 12: F13 LOAD-DEFLECTION LOOPS 


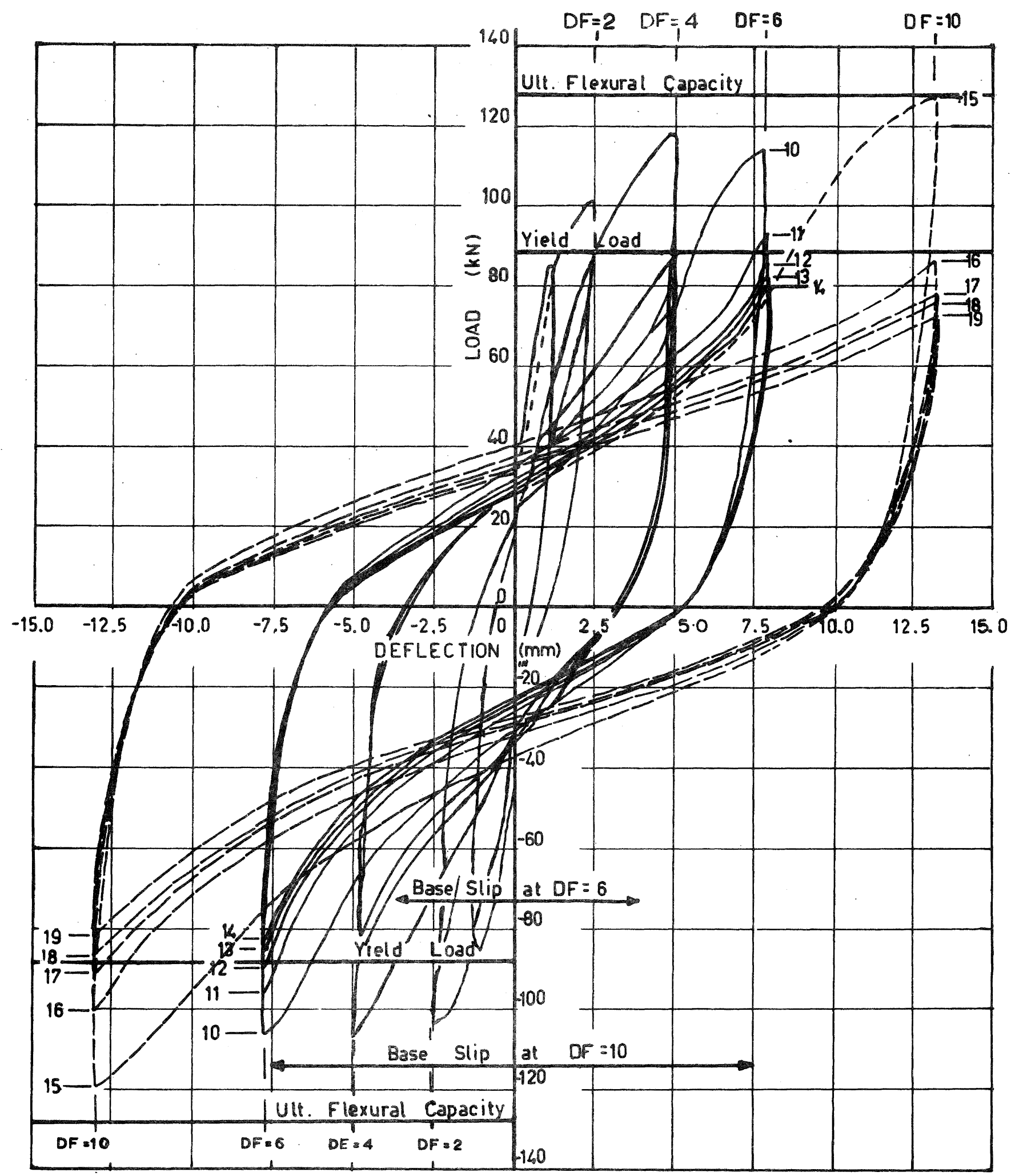

FIGURE 13: F15 LOAD-DEFLECTION LOOPS 


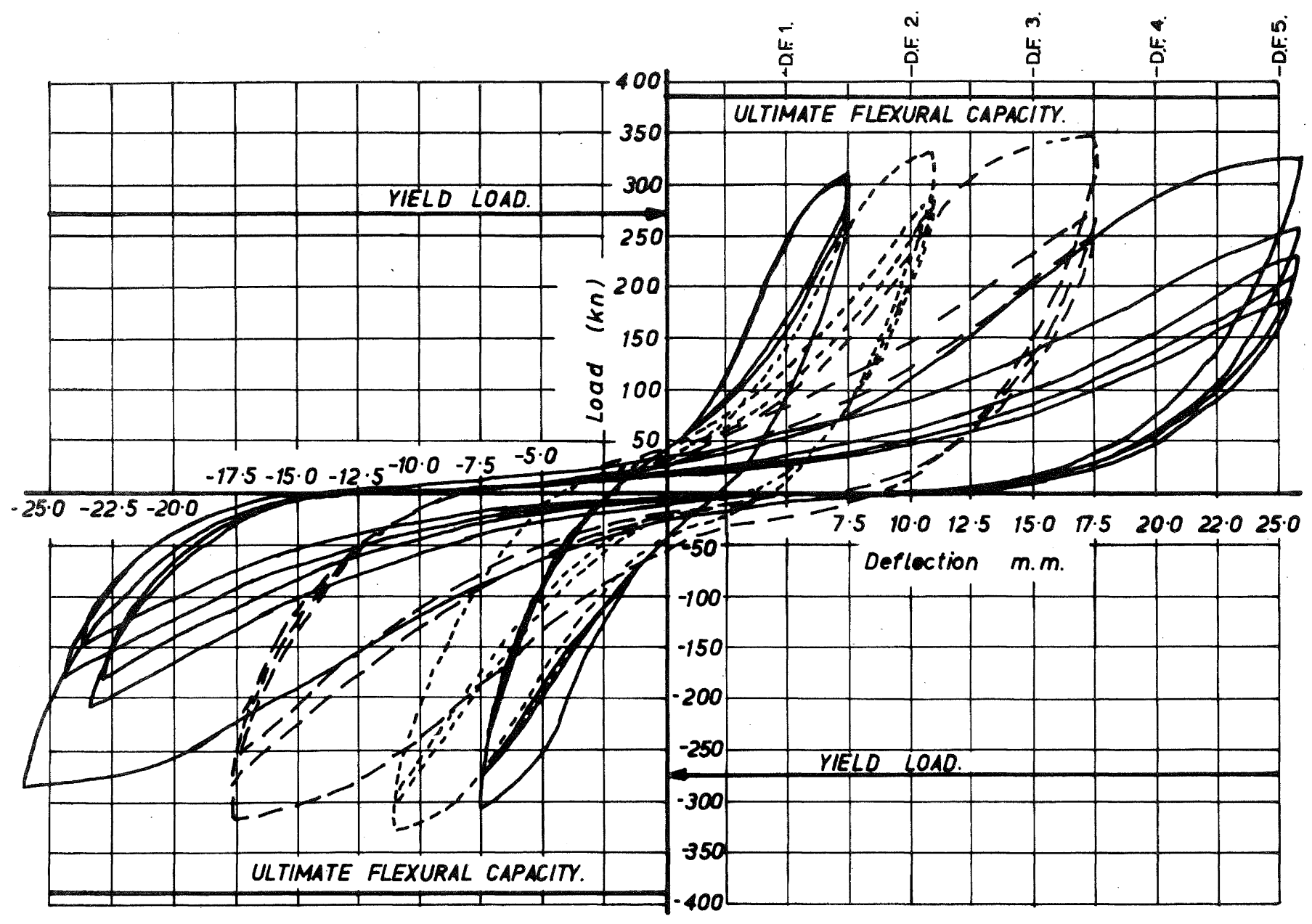

FIGURE 14: CBU-4 LOAD-DEFLECTION LOOPS 


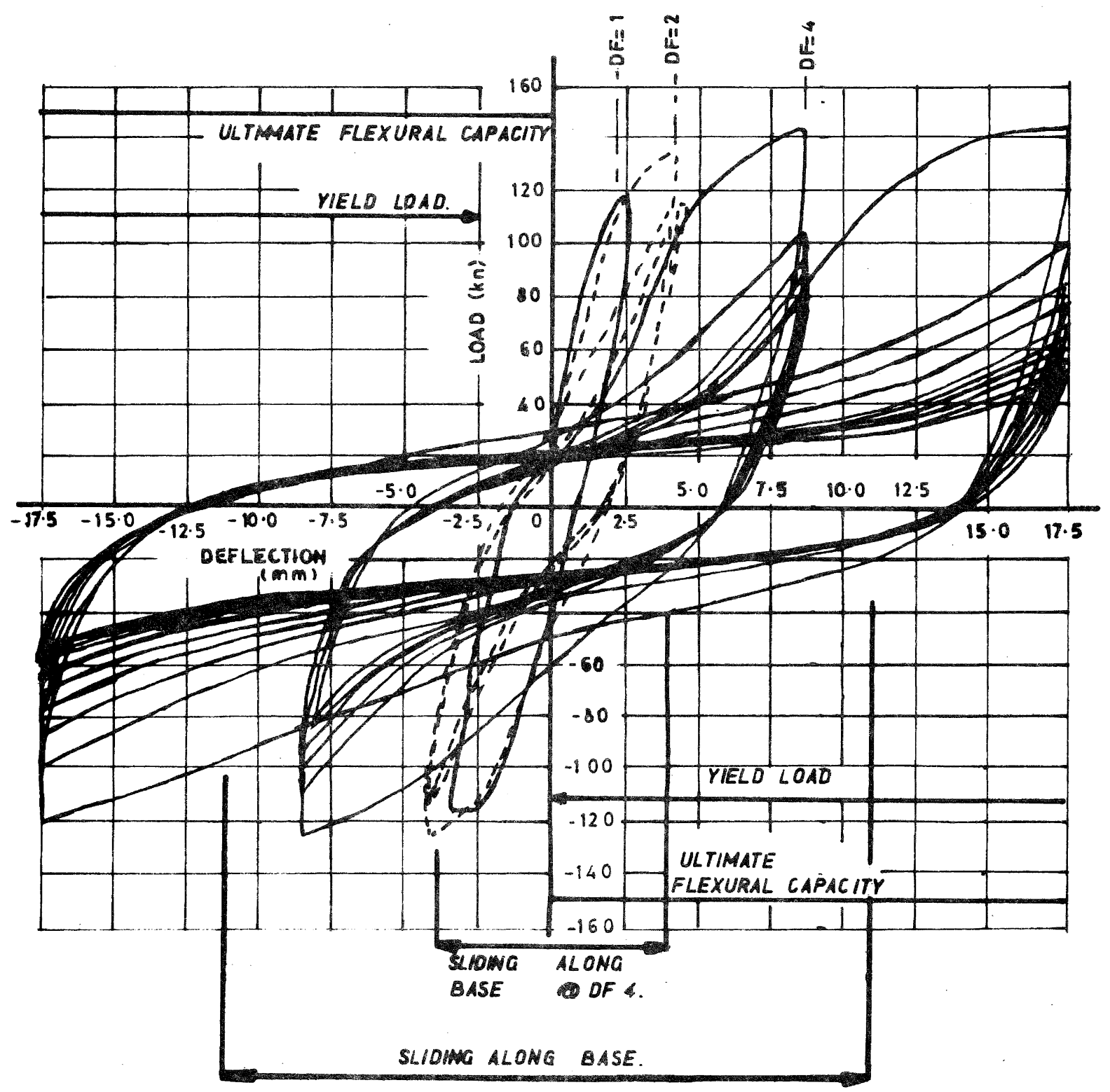

FIGURE 15: CBU-4 LOAD-DEFLECTION LOOPS 